\title{
Commentary on: Antibody and B cell responses to Plasmodium sporozoites
}

\author{
Jerome P. Vanderberg* \\ Department of Microbiology, New York University School of Medicine, New York, NY, USA \\ ${ }^{*}$ Correspondence: vandej01@nyumc.org \\ Edited by: \\ Urszula Krzych, Walter Reed Army Institute of Research, USA \\ Reviewed by: \\ Michael R. Hollingdale, Naval Medical Research Center, USA \\ Marita Troye-Blomberg, Stockholm University, Sweden
}

Keywords: malaria, plasmodium, sporozoite, immunity, antibodies, blood, liver, mosquitoes

\section{A commentary on}

Antibody and B cell responses to Plasmodium sporozoites

by Dups JN, Pepper M, Cockburn IA. Front Microbiol (2014) 5:625. doi: 10.3389/fmicb.2014.00625

Dups et al. (1) assess how antibody and B cell responses to Plasmodium sporozoites may function as protective immune responses. They cover immune induction quite extensively but discuss virtually nothing on effector mechanisms of antibody responses against sporozoites. Because their review should be balanced by reference to studies describing effector mechanisms, this commentary will confine itself to recounting some of these.

In vitro exposure to serum from immunized mice results in an antibody-mediated precipitant projecting from sporozoites (2). Because of the striking way in which immune serum deformed sporozoites, this "CSP" reaction was postulated to be the basis for a humoral component of immunity against sporozoites. In vitro inhibition of sporozoite motility by serum from immune animals subsequently suggested that anti-sporozoite antibodies can function by blocking sporozoite motility (3). Further in vitro studies showed that monoclonal antibodies against the CS antigen blocked in vitro invasion by sporozoites into target cells (4, 5). Subsequent intravital studies revealed in vivo inhibition of sporozoite motility and inhibition of sporozoite invasion of dermal blood vessels by antibodies (6). And an association between high levels of CS antibodies and protection was shown in the first successful human immunization with radiation-attenuated sporozoites (7).

Anti-sporozoite antibodies act even earlier during challenge by mosquito bite, by inhibiting release of sporozoites from the mosquito proboscis into skin (8). This appears to be the initial manifestation of functional immunity against preerythrocytic malaria parasites. Analysis of kinetics of Plasmodium berghei sporozoites injected by mosquitoes into sporozoiteimmunized vs. non-immunized mice showed significantly fewer sporozoites were deposited in immune mice (8). CS protein is released by sporozoites into media in vitro (9) and into saliva within salivary glands of infected mosquitoes $(10,11)$. Thus, CS protein released into mosquito saliva together with sporozoites is injected into hosts while mosquitoes probe for blood meals. This mosquitoinjected CS protein appears to interact with homologous anti-CSP antibodies within immunized hosts at sites of saliva release; the interaction produces immune complexes that interfere with free release of sporozoites by mosquitoes in vitro and in vivo (8).

Some sporozoites injected by mosquitoes into immunized hosts may successfully escape into the blood. Indeed, sporozoites that bypass skin by being injected intravenously by syringe into mice passively immunized with immune serum are cleared effectively from the circulation (12), indicating a functional role for antibodies against "break-through" sporozoites that have reached the blood.

Conceivably, antibody-coated sporozoites may be blocked during attempted passage through Kupffer cells prior to hepatocyte invasion $(13,14)$. In vitro studies have documented that opsonized sporozoites are prone to phagocytosis (15-17), suggesting that Kupffer cells can eliminate opsonized sporozoites in vivo. Furthermore, antibodies also inhibit invasion and traversal through hepatocytes, events that rely on sporozoite motility (18).

Thus, anti-sporozoite antibodies can act sequentially against sporozoites at different stages of sporozoite invasion from the skin to invasion of dermal blood vessels, to passage from Kupffer cells into hepatocytes, and subsequent traversal of sporozoites through a series of hepatocytes.

\section{REFERENCES}

1. Dups JN, Pepper M, Cockburn IA. Antibody and B cell responses to Plasmodium sporozoites. Front Microbiol (2014) 5:625. doi:10.3389/fmicb.2014. 00625

2. Vanderberg JP, Nussenzweig R, Most H. Protective immunity produced by the injection of $\mathrm{X}$ irradiated sporozoites of Plasmodium berghei. V. In vitro effects of immune serum on sporozoites. Mil Med (1969) 134:1183-90.

3. Vanderberg JP. Studies on the motility of Plasmodium sporozoites. J Protozool (1974) 21:527-37. doi:10.1111/j.1550-7408.1974.tb03693.x

4. Hollingdale MR, Zavala F, Nussenzweig RS, Nussenzweig V. Antibodies to the protective antigen of Plasmodium berghei sporozoites prevent entry into cultured cells. J Immunol (1982) 128:1929-30.

5. Hollingdale MR, Nardin EH, Tharavanij S, Schwartz AL, Nussenzweig RS. Inhibition of entry of Plasmodium falciparum and P. vivax sporozoites into cultured cells; an in vitro assay of protective antibodies. J Immunol (1984) 132:909-13.

6. Vanderberg JP, Frevert U. Intravital microscopy demonstrating antibody-mediated immobilisation of Plasmodium berghei sporozoites injected into skin by mosquitoes. Int J Parasitol (2004) 34:991-6. doi:10.1016/j.ijpara.2004.05.005

7. Clyde D, Most H, McCarthy V, Vanderberg JP. Immunization of man against sporozoiteinduced falciparum malaria. Am J Med Sci (1973) 
266:169-77. doi:10.1097/00000441-19731200000001

8. Kebaier C, Voza T, Vanderberg JP. Kinetics of mosquito-injected sporozoites in mice; fewer sporozoites are injected into sporozoiteimmunized mice. PLoS Pathog (2009) 5:e1000399. doi:10.1371/journal.ppat.1000399

9. Stewart MJ, Vanderberg JP. Malaria sporozoites release circumsporozoite protein from their apical end and translocate it along their surface. J Protozool (1991) 38:411-21. doi:10.1111/j.1550-7408. 1991.tb01379.x

10. Beier JC, Vaughan JA, Madani A, Noden BH. Plasmodium falciparum: release of circumsporozoite protein by sporozoites in the mosquito vector. Exp Parasitol (1992) 75:248-56. doi:10.1016/00144894(92)90185-D

11. Golenda CF, Burge R, Schneider I. Plasmodium falciparum and P. berghei: detection of sporozoites and the circumsporozoite proteins in the saliva of Anopheles stephensi mosquitoes. Parasitol Res (1992) 78:563-9. doi:10.1007/BF00936453

12. Nussenzweig RS, Vanderberg JP, Sanabria Y, Most H. Plasmodium berghei: accelerated clearance of sporozoites from blood as part of immune mechanism in mice. Exp Parasitol (1972) 31:88-97. doi:10.1016/0014-4894(72)90051-3
13. Pradel G, Frevert U. Malaria sporozoites actively enter and pass through rat Kupffer cells prior to hepatocyte invasion. Hepatology (2001) 33:1154-65. doi:10.1053/jhep.2001.24237

14. Baer K, Roosevelt $M$, Clarkson $\mathrm{AB} J r$, van Rooijen N, Schnieder T, Frevert U. Kupffer cells are obligatory for Plasmodium yoelii sporozoite infection of the liver. Cell Microbiol (2007) 9:397-412. doi:10.1111/j.1462-5822.2006. 00798.x

15. Danforth HD, Aikawa M, Cochrane AH, Nussenzweig RS. Sporozoites of mammalian malaria: attachment to, interiorization and fate within macrophages. J Protozool (1980) 27:193-202. doi: 10.1111/j.1550-7408.1980.tb04680.x

16. Seguin MC, Ballou WR, Nacy CA. Interactions of Plasmodium berghei. Sporozoites and murine Kupffer cells in vitro. J Immunol (1989) 143:1716-22.

17. Vanderberg JP, Chew S, Stewart MJ. Plasmodium sporozoite interactions with macrophages in vitro: a videomicroscopic analysis. J Protozool (1990) 37:528-36. doi:10.1111/j.1550-7408.1990. tb01260.x

18. Mota MM, Pradel G, Vanderberg JP, Hafalla JC, Frevert U, Nussenzweig RS, et al. Migration of Plasmodium sporozoites through cells before infection. Science (2001) 291:141-4. doi:10.1126/ science.291.5501.141

Conflict of Interest Statement: The author declares that the research was conducted in the absence of any commercial or financial relationships that could be construed as a potential conflict of interest.

Received: 18 January 2015; accepted: 28 February 2015; published online: 17 March 2015.

Citation: Vanderberg JP (2015) Commentary on: Antibody and B cell responses to Plasmodium sporozoites. Front. Immunol. 6:113. doi: 10.3389/fimmu.2015.00113 This article was submitted to Microbial Immunology, a section of the journal Frontiers in Immunology. Copyright (c) 2015 Vanderberg. This is an openaccess article distributed under the terms of the Creative Commons Attribution License (CC BY). The use, distribution or reproduction in other forums is permitted, provided the original author(s) or licensor are credited and that the original publication in this journal is cited, in accordance with accepted academic practice. No use, distribution or reproduction is permitted which does not comply with these terms. 